\title{
Survival rate and growth in the wild of sea trout (Salmo trutta L.) fry obtained using frozen semen
}

\author{
Józef Domagała, Katarzyna Dziewulska, Robert Czerniawski
}

Received - 13 February 2014/Accepted - 21 September 2014. Published online: 31 December 2014; $\odot$ Inland Fisheries Institute in Olsztyn, Poland Citation: Domagała J., Dziewulska K., Czerniawski R. 2014 - Survival rate and growth in the wild of sea trout (Salmo trutta L.) fry obtained using frozen semen - Arch. Pol. Fish. 22: 265-270.

\begin{abstract}
The aim of the study was to assess the growth and development of sea trout, Salmo trutta L., fry obtained from frozen, thawed semen after the fish had been released into the wild and were feeding there. The semen was cryopreserved with either methanol (MeOH) or dimethyl sulfoxide (DMSO). Fresh eggs were collected and fertilized with the thawed semen. The control was eggs fertilized with fresh semen that had been kept on ice. The eggs were incubated and reared in a closed recirculating system. The fertilized eggs were counted for visible eye pigment. After rearing, three groups of fish were tagged and stocked into a stream. The fish aged 6 months were caught from the stream. The fish were measured, weighed, identified to which experimental variant they belonged, and their survival rate was estimated. No significant differences in survival rate, length, weight, or condition factor among the control, DMSO, and $\mathrm{MeOH}$ groups were noted during larval development in a closed recirculating system. These parameters were also similar in the control and experimental groups after the fish had grow in a natural stream. The use of frozen semen to fertilize fresh sea trout eggs resulted in a normal incubation process, larval stage, and regular fry growth and survival, both under laboratory conditions, and, most importantly, in the wild. The results indicate it is possible to use frozen semen for fry production and the restoration of wild fish populations.
\end{abstract}

\footnotetext{
J. Domagała [ $\left.\Xi^{\circ}\right]$, K. Dziewulska, R. Czerniawski

Department of General Zoology

Faculty of Biology

University of Szczecin, Poland

ul. Felczaka 3c, 71-412 Szczecin

e-mail: Jozef.Domagala@univ.szczecin.pl
}

Keywords: Salmonid, Salmo trutta, cryopreservation, fish stocking, growth rate

\section{Introduction}

Seat trout Salmo trutta L. resources in the rivers of Western Pomerania have diminished systematically primarily because of increasing human impact on the environment. At the same time, actions have been undertaken that are intended to restore resources of this fish, mainly by stocking Polish marine areas (Bartel 1992, 2004, 2012). Stocking material is acquired from fish farms that obtain spawn by induced reproduction of trout on spawning migrations from the sea to rivers annually each fall, and then this material is reared to the smolt stage. Currently, conditions for acquiring natural spawners from Polish rivers are deteriorating. At times there is a shortage of spawners, and maintaining a supply of good quality sperm until the end of the breeding season is also a problem. Thus, when the availability of reproductive products from fish undertaking spawning migrations is limited, the possibility of fertilizing freshly deposited eggs with sperm that has been frozen in liquid nitrogen and deposited in Dewar flasks had to be tested. When freezing gametes in liquid nitrogen the physical factors and chemical properties of the cryodiluent can have a destructive effect on the cells. 
Damage to DNA, plasmalema, the motility apparatus, and cell metabolism as well as others injuries have been noted (Ogier de Baulny et al. 1997, Cabrita et al. 1998, 2005, Drokin et al. 1998, Labbe et al. 2001, Tiersch et al. 2004). The damage inflicted on the thawed spermatozoa can influence the life functions of the offspring obtained from eggs fertilized with frozen semen, and this can appear at different stages of ontogenesis. Therefore, observing the development of offspring is required (Horváth and Urbányi 2000, Young et al. 2009). Research on survival rates and malformation of progeny has been performed mostly to the larval stage.

To date, we have demonstrated that sea trout larvae produced with these methods grow and develop very well in closed circulation conditions until they are three months old, and that the cryoprotectant (methanol) used in freezing has no adverse affect on the growth of the developing fry (Dziewulska et al. 2012). In the present study, we plan to test the effect of two cryoprotectants-dimethy sulfoxide (DMSO) and methanol $(\mathrm{MeOH})$-on the development of progeny up to and including the feeding period in a natural stream. These cryoprotectants are used commonly in fish spermatozoa cryopreservation (Lahnsteiner et al. 1997, Cabrita et al. 2001, Mansour et al. 2006, Jodun et al. 2006, Ciereszko et al. 2014). The aim of this work was to check the pattern of growth and development of sea trout alevins obtained from frozen, thawed semen that had been cryopreserved with methanol or dimethyl sulfoxide after stocking and during the period of feeding in the wild to the age of six months.

\section{Materials and methods}

On November 13, 2008, sperm from six adult sea trout males of 55-60 cm was collected in the Reda River near Trzebiatów. Eggs produced by three females measuring 65-70 $\mathrm{cm}$ was also collected. The reproduction products were held on ice and shipped in plastic containers at temperatures of $2-4^{\circ} \mathrm{C}$ to the laboratory at the Department of General Zoology and subject to testing. Sperm quality was evaluated using the latest measurement methods (CASA) (Dziewulska et al. 2011), and sperm cells from three males with a motility of $80 \%$ were selected. Next, the semen was mixed in three equal volumes, computer analysis of sperm cell movement was conducted, and semen concentration was determined (16.1 bn ml${ }^{-1}$ ). Some of the semen was then frozen using the standard method for salmonid fishes in liquid nitrogen in $0.25 \mathrm{ml}$ straws diluted in a mixture of $0.3 \mathrm{M}$ glucose, $10 \%$ egg yolk, and either $10 \%$ methanol $(\mathrm{MeOH})$ or 10\% dimethyl sulfoxide, proportionally (Dziewulska et al. 2012). The straws were placed on a polystyrene frame at a height of $4 \mathrm{~cm}$, in liquid nitrogen vapor, and after three minutes they were dropped into the nitrogen. After one hour of freezing, the semen in the straws was thawed at $40^{\circ} \mathrm{C}$ for $5-6 \mathrm{~s}$ and then used to fertilize the eggs.

Eggs from the three females were also mixed in three equal volumes, and 14 samples of 100 eggs each were collected and fertilized with the thawed semen, half of which had been frozen with methanol and half with dimethyl sulfoxide. The control was eggs fertilized with fresh semen kept on ice, with three repetitions (mixed fresh semen was obtained from the same fish that the frozen semen was obtained). The egg/semen ratio was 1:400 $\times 10^{3}$ when the eggs were fertilized with fresh semen; while it was ten times higher when the eggs were fertilized with thawed semen. After pouring the semen over the eggs, the gametes were mixed for 20-30 s, and after two to three $\mathrm{m}$, the fertilized eggs were rinsed three times by adding $50 \mathrm{ml}$ water from a closed circulating system and left for $60 \mathrm{~m}$. Next, numbered basins were stocked with eggs and placed into aquariums in the closed circulating system in the aquarium room at the department. During incubation, eggs with non-developing embryos were counted and discarded. Later, the fertilized eggs with visible eye pigment were counted. The larvae absorbed the yolk sacs for nearly three weeks. On January 21, aquariums with a capacity of 551 were stocked with weighed and measured larvae with each tank holding approximately 100 fish, in three variants with three repetitions. The experiment lasted until April 16. 
Measurements of the growing fish were conducted every two weeks on ten specimens. The water column was $20 \mathrm{~cm}$ high. Water temperature was kept at $10-13^{\circ} \mathrm{C}$ and water flow was $3001 \mathrm{~h}^{-1}$. The chemical and physical parameters of the water were recorded three times daily. During rearing, the $\mathrm{N}-\mathrm{NH}_{3}$ concentration was $0.008 \mathrm{mg} \mathrm{l}^{-1} \pm 0.005$, diluted oxygen was $8.40 \mathrm{mg} \mathrm{l}^{-1} \pm 0.35$, and $\mathrm{pH}$ was $7.98 \pm 0.42$. The larvae were fed ad libitum. Their first food was live zooplankton caught in ponds. Next, they were provided with Artemia nauplii, Chironomidae larvae, and fly (Muscidae) larvae. The food was delivered from 07:00 to $17: 00$ every three hours. The survival rate and growth of larvae that were starting to feed was monitored for a three-months rearing period. Fork length $\left(\mathrm{L}_{\mathrm{F}}\right)$ was recorded to the nearest $0.5 \mathrm{~mm}$ and weight $(\mathrm{W})$ to the nearest $0.001 \mathrm{~g}$. After manipulation, the fish were returned to the tanks. The condition factor $\left(\mathrm{K}_{\mathrm{F}}\right)$ was calculated with the following formula: $\mathrm{K}_{\mathrm{F}}=10^{5} \times \mathrm{W} \times \mathrm{LF}_{\mathrm{F}}^{-3}$.

After the aquarium experiment was completed, the fish were marked. The fish in the control group were marked with alizarin according to standard procedures (Tsukamoto 1988, Pelczarski and Czerkies 2003); the fish developed from fertilization with semen frozen with dimethyl sulfoxide had their flesh fin removed, and the fish from semen frozen with methanol were unmarked. The fish were held for a week and then released into the Trawna stream. We have used this stream for many years for rearing trout and Atlantic salmon, Salmo salar L., fry. The fish were caught subsequently with electrofishing. For stocking purposes, we used the middle section of the stream, where other fish species are absent. Water temperature, oxygen content, and $\mathrm{pH}$ are appropriate for the growth of salmonid fishes. Nutrient availability in the stream is also high. The stream is characterized by a high percentage of Gammaridae and Chironomidae larvae in the total amount of macroinvertebrates (Czerniawski et al. 2007). These taxa are among the most common food components eaten by salmonid fish at this age (Amundsen et al. 2000).

The fish grew in the stream for three months, and they were subsequently caught (on July 23, 2009 at the age of 6 months) in the manner indicated above. The fish were measured (fork length) and weighed, and otoliths were extracted from some fish to check for the presence of the alizarin marker. The fish were identified as belonging a given experimental group, and then their average body length, mass, and survival rates were calculated. The fork length of the fish captured from the stream was recorded to the nearest $0.1 \mathrm{~cm}$ and weight to the nearest $0.1 \mathrm{~g}$. Condition factor was calculated using the following formula:

$$
\mathrm{K}_{\mathrm{F}}=100 \times \mathrm{W} \times \mathrm{LF}_{\mathrm{F}}^{-3} \text {. }
$$

The significance of differences in the survival rates of the fish was tested with the chi-square test, and one-way ANOVA was used to analyze the significance of differences in weight, length, and condition factor between the control group and the two experimental groups. Tukey's test was used for all post-hoc comparisons. All statistical procedures were performed with Statistica v.10.0 software at a significance level of 0.05 . The data are presented as means \pm SD.

\section{Results}

The fertilization capacity of the fresh semen was high (94\%), whereas that of the sperm frozen with methanol and dimethyl sulfoxide was more than two times lower. Of those, an insignificantly higher percentage of fertilized eggs were obtained from semen frozen with methanol (42\%) than with dimethyl sulfoxide (37\%). The survival rate of the fish from spawning to hatching and the start of feeding was high and similar in the three groups tested at 96.6, 97, and 96.2\%, respectively, from fertilization to hatching $(\mathrm{P}>0.05)$ and from 98.7, 98.8, and 100\%, respectively, from hatching to the start of feeding $(\mathrm{P}>0.05)$. Larval body mass and body length at the start of feeding in the three groups was approximately as follows: control $-25.6 \pm 0.88 \mathrm{~mm}$ and $0.11 \pm 0.01 \mathrm{~g}$; methanol group - $25.6 \pm 0.68 \mathrm{~mm}$ and $0.12 \pm 0.01 \mathrm{~g}$; DMSO group $-25.2 \pm 1.12 \mathrm{~mm}$ and $0.12 \pm 0.02 \mathrm{~g}(\mathrm{P}>$ 0.05). During the aquarium experiment, survival rates were high, as follows: control $-35.1 \pm 2.09 \mathrm{~mm}$ and $0.40 \pm 0.12 \mathrm{~g}$; methanol group $-33.9 \pm 2.89$ 
Table 1

Survival and growth of sea trout (S. trutta) alevins in a stream; mean \pm SD. MeOH group - fish obtained from fertilization with semen frozen with methanol, DMSO group - fish obtained from fertilization with semen frozen with dimethyl sulfoxide

\begin{tabular}{|c|c|c|c|c|c|c|c|c|c|}
\hline \multirow[b]{2}{*}{ Groups } & \multirow[b]{2}{*}{$\begin{array}{l}\text { Stocked } \\
\text { fish }\end{array}$} & \multirow[b]{2}{*}{$\begin{array}{l}\text { Captured } \\
\text { fish }\end{array}$} & \multirow[b]{2}{*}{$\begin{array}{l}\text { Efficiency } \\
(\%)\end{array}$} & \multicolumn{3}{|c|}{$\begin{array}{l}\text { Basic fish characteristics on the day } \\
\text { of release }\end{array}$} & \multicolumn{3}{|c|}{$\begin{array}{l}\text { Basic fish characteristics on the day } \\
\text { of capture }\end{array}$} \\
\hline & & & & $\begin{array}{l}\text { Length } \\
(\mathrm{cm})\end{array}$ & $\begin{array}{l}\text { Weight } \\
(\mathrm{g})\end{array}$ & $\begin{array}{l}\text { Condition } \\
\text { factor }\end{array}$ & $\begin{array}{l}\text { Length } \\
(\mathrm{cm})\end{array}$ & $\begin{array}{l}\text { Weight } \\
\text { (g) }\end{array}$ & $\begin{array}{l}\text { Condition } \\
\text { factor }\end{array}$ \\
\hline Control group & 89 & 42 & 47.2 & $3.5 \pm 0.2$ & $0.40 \pm 0.12$ & $0.92 \pm 0.16$ & $12.0 \pm 0.9$ & $17.4 \pm 3.2$ & $1.0 \pm 0.1$ \\
\hline $\mathrm{MeOH}$ group & 94 & 51 & 54.2 & $3.4 \pm 0.3$ & $0.36 \pm 0.12$ & $0.93 \pm 0.10$ & $11.1 \pm 0.6$ & $17.1 \pm 3.4$ & $1.3 \pm 0.1$ \\
\hline DMSO group & 101 & 55 & 54.4 & $3.6 \pm 0.3$ & $0.44 \pm 0.15$ & $0.93 \pm 0.10$ & $11.1 \pm 0.8$ & $17.2 \pm 3.1$ & $1.3 \pm 0.2$ \\
\hline
\end{tabular}

$\mathrm{mm}$ and $0.36 \pm 0.12 \mathrm{~g}$; DMSO group $-35.7 \pm 3.42$ $\mathrm{mm}$ and $0.44 \pm 0.15 \mathrm{~g}$. These differences were not statistically significant $(\mathrm{P}>0.05)$. After the completion of the experiment in the aquarium room, the fish were marked and one week later they were released into the Trawna stream, as follows: control - 89 fish; DMSO - 101 fish; MeOH - 94 fish. On average, fish body length exceeded $11 \mathrm{~cm}$ and the average mass exceeded $17 \mathrm{~g}$, whereas the condition coefficient was 1.2 (Table 1). During feeding in the wild, no significant differences in the characteristic mentioned above among the control, DMSO, and $\mathrm{MeOH}$ groups were noted $(\mathrm{P}>0.05)$. We caught 42,51 , and 55 fish that represented $47.2,54.2$, and $54.4 \%$, respectively, of settled, healthy fish, in good condition, and showing no symptoms of disease. The survival rate in the wild did not differ significantly among the studied groups $(\mathrm{P}>0.05)$.

\section{Discussion}

The first conclusion drawn from the observations of fish growth and survival rate under laboratory conditions was that the differences noted referred primarily to the fertilization rates of the fresh and frozen sperm. The fertilization rates with the frozen sperm were considerably lower, and were not comparable to those of the fresh sperm. Similar results were recorded before (Dziewulska et al. 2012). During both egg incubation and larval growth to the feeding stage, survival rates were high and comparable in all variants, just as is reported in earlier studies (Dziewulska et al. 2012). The fish grew during the first three months in aquariums and exhibited good, similar growth with high, comparable survival rates.

After the fish were released into the natural stream, growth was very good in all variants. After capture three months later in the middle of the feeding season, fish length exceeded $11 \mathrm{~cm}$ and body mass 17 g. These favorable results were probably the result of food conditions in the stream, which are characterized by a high percentage of Gammaridae and Chironomidae larvae in the total amount of macroinvertebrates (Czerniawski et al. 2007). These organisms are among the most common food components consumed by salmonid fishes at this age, which confirms the food selectivity of juvenile salmonid fishes for these organisms (Amundsen et al. 2000).

The major problem of salmonid restoration in the wild is high mortality. Despite many attempts and annual stocking, parr-to-smolt survival is still low and does not exceed 20-30\% (Brown and Day 2002, Achord et al. 2007). The parr-to-adult salmonid survival rates are even worse at 1-5\% (McNeil 1991, Salvanes 2001). Stocking with hatchery-reared fish is a popular way to restore salmonid populations (Domagala and Bartel 1997, Jonsson and Jonsson 2006). However, studies have shown that hatchery-reared fish mortality is at least twice as high as that of wild fish (Sväsand et al. 1989, Weber and Fausch 2003, Jonsson and Jonsson 2006).

In the present study, the survival rate was very high, and it approximated the rate for summer trout 
in this stream recorded during experiments conducted in previous years (Domagała and Trzebiatowski 1990, Trzebiatowski and Domagała 1990a, 1990b). However, it was varied and was highest among fish that had not been manipulated or manipulated minimally. The survival of the control group treated with alizarin, which had been subjected to additional procedures, was lower. Satisfactory fry survival rates could be obtained by rearing fry on live food before releasing them into the wild. The study results indicate that the quality of the food administered in the rearing stage can affect fish growth and survival under natural conditions considerably. The food used in the present study during fish rearing under controlled conditions permitted achieving much higher survival rates after stocking than does standard feed. The results obtained by Czerniawski et al. (2009) show that rearing sea trout larvae in a nursery using live zooplankton can increase survival in streams by $20 \%$ in comparison to the same material reared on feed. Even better results were observed when Atlantic salmon and sea trout fry reared on live zooplankton under controlled conditions were released into streams. Atlantic salmon and sea trout fall fry reared on live zooplankton and then released as into streams as feeding fry achieved survival rates that were 50 and $40 \%$ higher, respectively, than those of the same stock reared on standard feed (Czerniawski et al. 2011, 2015). What is more, favorable survival rates were affected by the absence of predators. Survival and growth might also be affected by predatory fish species (Kennedy and Strange 1986). In some cases, predators can cause over $90 \%$ mortality rates among salmonid fish fry (Kelly-Quin and Bracken 1989). It should be added that over three months the fish dispersed within an area of about $800 \mathrm{~m}^{2}$, just as in earlier trout experiments conducted in this stream (Domagała and Trzebiatowski 1990, Trzebiatowski and Domagała 1990b, 1990b). Therefore, using frozen semen to fertilize fresh trout eggs results in a normal incubation process, larva stage, and regular fry growth and survival, both under laboratory conditions and in a natural stream. Thus, it can be used for the natural reproduction of endangered fish species.
Acknowledgments. This study was realized within the Operational Programme „Sustainable Development of the Fisheries Sector and Coastal Fishing Areas 20072013". Agreement no. OR1600004 00001-61724/10.

Author contributions. J.D, K.D. and R.C. designed and performed the experiment, analyzed the data, and wrote the manuscript.

\section{References}

Achord S., Zabel R.W., Sandford B.P. 2007 - Migration timing, growth, and estimated parr-to-smolt survival rates of wild Snake River spring-summer Chinook salmon from the Salmon River basin, Idaho, to the lower Snake River Trans. Am. Fish. Soc. 136: 142-154.

Amundsen P.A., Gabler H.M., Herfindal T., Riise L.S. 2000 Feeding chronology of Atlantic salmon parr in subarctic rivers: consistency of nocturnal feeding - J. Fish Biol. 56: 676-686.

Bartel R. 1992 - Is this the end for salmon and sea trout? Komun. Ryb. 1: 1-5 (in Polish).

Bartel R. 2004 - Guidelines for choosing salmon and sea trout smolts and fry for restocking Polish marine areas Komun. Ryb. 3: 15-24 (in Polish).

Bartel R. 2012 - Guidelines for choosing stocking material for restocking Polish marine areas - Komun. Ryb. 2: 24-32 (in Polish).

Brown C., Day R.L. 2002 - The future of stock enhancements: lessons for hatchery practice from conservation biology Fish Fish. 3: 79-94.

Cabrita E., Alvarez R., Anel L., Rana K.J., Herráez M.P. 1998 - Sublethal damage during cryopreservation of rainbow trout sperm - Cryobiology 37: 245-253.

Cabrita E., Robles V., Alvarez R., Herráez M.P. 2001 - Cryopreservation of rainbow trout sperm in large volume straws: application to large scale fertilization Aquaculture 201: 301-314.

Cabrita E., Robles V., Rebordinos L., Serasquete C., Herráez MP. 2005 - Evaluation of DNA damage in rainbow trout (Oncorhynchus mykiss) and gilthed sea bream (Sparus aurata) cryopreserved sperm - Cryobiology 50: 144-153.

Ciereszko A., Dietrich G.J., Nynca J., Dobosz S., Zalewski T. 2014 - Cryopreservation of rainbow trout semen using a glucose-methanol extender - Aquaculture 420-421: 275-281.

Czerniawski R., Pilecka-Rapacz M., Domagała J. 2007 Macrofauna of the three small streams as a prospective food reservoir for juvenile salmonids - Acta Sci. Pol., Pisc. 6: 3-12. 
Czerniawski R., Domagała J., Pilecka-Rapacz M. 2009 Rearing of sea trout fry (Salmo trutta trutta L.) - as potential stocking material, with living zooplankton and dry prepared food - EJPAU, Fisheries 12 (4) http://www.ejpau.media.pl/volume12/issue4/art-14.ht $\mathrm{ml}$.

Czerniawski R., Pilecka-Rapacz M., Domagała J. 2011 Stocking experiment with Atlantic salmon and sea trout parr reared on either live prey or a pellet diet - J. Appl. Ichthyol. 27: 984-989.

Czerniawski R., Domagała J., Krepski T., Pilecka-Rapacz M. 2015 - Impact of live food on survival and growth of hatchery-reared sea trout (Salmo trutta trutta L.) parr in the wild - J. Appl. Ichthyol. 31: 95-99.

Domagala J., Bartel R. 1997 - Survival and growth of the reared and wild hatch of salmon released into small streams - Komun. Ryb. 1: 34-38 (in Polish).

Domagała J., Trzebiatowski R. 1990 - Comparison of released floating and reared larval sea trout (Salmo trutta L.) survival in six streams - Proc. Conf. Optimizing water management and fish husbandry in a deteriorating natural environment, Szczecin, 25-26.09.1990, Wyd. AR, Szczecin: 19-21 (in Polish).

Dziewulska K., Rzemieniecki A., Domagała J. 2011 - Sperm motility characteristics of wild Atlantic salmon (Salmo salar L. ) and sea trout (Salmo trutta m. trutta L.) as a basis for milt selection - J. Appl. Ichthyol. 27: 1047-1051.

Dziewulska K., Czerniawski R., Goździk I., Domagała J. 2012 - Survival and growth of sea trout (Salmo trutta m. trutta L.) fry obtained using frozen semen - Komun. Ryb. 6: 6-9 (in Polish).

Horváth Á., Urbányi B. 2000 - The effect of cryoprotectants on the motility and fertilizing capacity of cryopreserved African catfish Clarias gariepinus (Burchell 1822) sperm -Aquacult. Res. 31: 317-324.

Jodun W.A., King K., Farrell P., Wayman W. 2006 - Methanol and egg yolk as cryoprotectants for Atlantic salmon spermatozoa - N. Am. J. Aquacult. 69: 36-40.

Jonsson B., Jonsson N. 2006 - Cultured Atlantic salmon in nature: a review of their ecology and interaction with wild fish - J. Mar. Sci. 63: 1162-1181.

Kelly-Quinn M., Bracken J.J. 1989 - Survival of stocked hatchery - reared brown trout, Salmo trutta L., fry in relation to the carrying capacity of a trout nursery stream Aquacul. Res. 20: 211-226.

Kennedy G.J.A., Strange C.D. 1986 - The effects of intra- and inter- specific competition on the survival and growth of stocked juvenile Atlantic salmon Salmo salar L. and resident trout Salmo trutta L. in an upland stream - J. Fish Biol. 28: 479-489.

Labbe C., Martoriati A., Devaux A., Maisse G. 2001 - Effect of sperm cryopreservation on sperm DNA stability and progeny development in rainbow trout - Mol. Reprod. Dev. 60: 397-404.

Lahnsteiner F., Weismann T., Patzner R.A. 1997 - Methanol as cryoprotectant and the suitability of $1.2 \mathrm{ml}$ and $5 \mathrm{ml}$ straws for cryopreservation of semen from salmonid fishes - Aquacult. Res. 28: 471-479.

Mansour N., Richardson G.F., McNiven M.A. 2006 - Effect of extender composition and freezing rate on post-thaw motility and fertility of Arctic char, Salvelinus alpinus (L.), spermatozoa - Aquacult. Res. 37: 862-868.

McNeil W. 1991 - Expansion of cultured Pacific salmon into marine ecosystems - Aquaculture 98: 173-183.

Ogier de Baulny B., Le Vern Y., Kerboeuf D., Maisse G. 1997 - Flow cytometric evaluation of mitochondrial activity and membrane integrity in fresh and cryopreserved rainbow trout (Oncorhynchus mykiss) spermatozoa Cryobiology 34: 141-149.

Pelczarski W., Czerkies P. 2003 - Using fluorescence immersion marking in the restitution of whitefish in the Puck Bay - Acta Sci. Pol., Pisc. 2: 207-218.

Salvanes A.G.V. 2001 - Ocean Ranching - In: Encyclopedia of Ocean Sciences (Eds) J. Steele, K.K. Turkian, S.A. Thorpe, Acad. Press, London, 4: 1973-1982.

Sväsand T., Skilbre O.T., Van der Meeren G.I., Holm M. 1989 - Review of morphological and behavioural diferences between reared and wild individuals: implications for sea-ranching of Atlantic salmon, Salmo salar L., Atlantic cod, Gadus morhua L. and European lobster, Homarus gammarus L. - Fish. Manag. Ecol. 5: 1-18.

Tiersch T.R., Wayman W.R., Skapura D.P., Neidig C.L., Grier H.J. 2004 - Transport and cryopreservation of sperm of the common snook, Centropomus undecimalis (Bloch) Aquacult. Res. 3: 278-288.

Trzebiatowski R., Domagała J. 1990a - Efficiency of stoking small streams with the see-trout (Salmo trutta L.) hatch of different age - ICES ( $80^{\text {th }}$ Statutory Meeting) C.M 1990/M;13.

Trzebiatowski R., Domagała J. 1990b - Increasing the effectiveness of restocking streams with sea trout larvae Zesz. Nauk. AR Wrocław, Zoot. 34(200): 177-181 (in Polish).

Tsukamoto K. 1988 - Otolith tagging of ayu embryo with fluorescent substances - Nippon Suisan Gakk. 54: 1289-1295.

Young W.P., Frenyea K., Wheeler P.A., Thorgaard G.H. 2009 - No increase in developmental deformities or fluctuating asymmetry in rainbow trout (Oncorhynchus mykiss) produced with cryopreserved sperm - Aquaculture 289: 13-18.

Weber E.D., Fausch K.D. 2003 - Interactions between hatchery and wild salmonids in streams: differences in biology and evidence for competition - Can. J. Fish. Aquat. Sci. 60: 1018-1036. 